\title{
Analysis of Socio-Economic Characteristics and Utilization of Healthcare Facilities in Owo Local Government Area of Ondo State, Nigeria
}

\author{
Omotayo Ben Olugbamila, PhD \\ Samson Ajibola Adeyinka, PhD \\ Department of Urban and Regional Planning, \\ Obafemi Awolowo University, Ile-Ife, Nigeria
}

doi: 10.19044/esj.2017.v13n23p377 URL:http://dx.doi.org/10.19044/esj.2017.v13n23p377

\begin{abstract}
This paper examines the socio-economic characteristics of residents and their utilization of available healthcare facilities in Owo local government area of Ondo State, Nigeria. The data utilized in the paper draws on systematic sampling of 368 health consumers in the study area. Findings revealed that socio-economic characteristics play a significant role in determining the frequency of visits to healthcare facilities, this is substantiated with the chi-square test result that revealed a significant relationship between marital status and frequency of visits to healthcare facilities with $\chi^{2}=29.175$ and significant at $p=0.004$ level, as well as income of households and the frequency of visits to healthcare facilities with $\chi^{2}=20.961$ and significant at $\mathrm{p}=0.007$ levels. The paper therefore concluded that efforts should be put in place to improve the socio-economic status of individuals through multi-sectoral development activities such as micro-credit facilities and provision of employment opportunities which is believed will invariably improve their access and utilization of healthcare facilities.
\end{abstract}

Keywords: Frequency of Visits, Healthcare, Owo LGA, Socio-Economic, Utilization

\section{Introduction}

Health is a concept that relates to and describes a person's state of well-being; it encompasses physical and psychological well-being and not simply absence of disease. Its importance to human being cannot be overemphasized. No wonder, Ogundare (1982) cited in Olugbamila (2016) linked health to man's existence as food is important to individual existence, and was of the opinion that the concern and attention that any government pays 
to health could well determine the well-being of the people. Health therefore is a basic requirement of every citizen in a country. The health of man is important, because all economic activities are mainly carried on by man and as posited by Adeyinka (2006) that health is the output that people desire and not health services (input) per se for the accomplishment of improved standard of living for them. Indeed, the health of the people is not only considered to contribute to better quality of life but also essential for the sustained economic and social development of a country as a whole (Federal Ministry of Health (FMOH), 2004). According to the UN (2000), health is considered a fundamental human right indispensable for the exercise of other human rights. Every human being is entitled to the enjoyment of the highest attainable standard of health conducive to living a life in dignity. Health related issues therefore are of strategic concern to all including government, professionals and consumers, hence government and stakeholders in the health sector are concerned and focused on the provision and maintenance of such levels of healthcare that will make it possible for individuals to live socially and economically a productive life.

The major concern of the World Health Organization (WHO) is the provision of quality and affordable healthcare for everyone irrespective of varying levels of living (Ibor and Atomode, 2014). In other words, whether in the advanced or poor countries, rural or urban areas, for the poor or the rich; provision, accessibility and utilization of healthcare facilities remain the focus of all governments in the world. It is in view of this that every levels of government in Nigeria holds the view that a healthy population is essential for rapid socio-economic development of the country hence, healthcare is on the concurrent list in the Nigerian constitution and most often, its allocation comes next to education and defence in the national budget of every year. Moreover, the Federal, State and Local Governments have formulated various policies, at one time or the other, which tended to focus attention on providing and equipping health facilities and recruitment of more health workers to make health services more accessible to the people which will aid its utilization. Healthcare facilities utilization therefore is the willingness of the potential patients to make the most of the services offered at a medical establishment. The utilization of healthcare facilities is an important policy concern in most developing countries, Nigeria inclusive. Utilization is determined by the type of health services available to a population and this resulted to many urban residents in developing cities travelling over a long distances and spend a large proportion of their income in order to procure healthcare services which are relatively provided elsewhere (Adesanya et al, 2002; Adetunji, 2010)

The need for healthcare facilities, its utilization and access of residents to the available healthcare facilities cannot be over-emphasized. It 
is an important component of the overall health system which has impact on the well-being of residents in a particular location. Yang, George and Mullner (2006) remarked that equitable distribution of healthcare resources is one of the main goals of healthcare facility planning. It has therefore been established in literature that uneven distribution of healthcare facilities has increased the percentage of income spent on healthcare services (Olugbamila, 2016) as well as the distance that a prospective health seeker have to travel to enjoy the available healthcare services (Buor, 2003). It is a general consensus that few people are willing to utilize a particular facility as the distance from it increases (Balogun and Alaegor, 2006 and Adetunji, 2013).

Studies have shown that people of low socio-economic status are vulnerable to a lot of health hazards some of which can actually be preventable and curable with the existing healthcare facilities in their immediate communities (Adeyinka and Olugbamila, 2016). Consequently a lot of death has been recorded against the people of low socio-economic status as a result of their inadequate utilization of healthcare facilities in their immediate communities (Owoseni et al, 2014). This paper therefore investigates the role of socio-economic characteristics in the utilization of healthcare facilities in Owo local government area of Ondo State, Nigeria.

\section{Literature Review}

Awoyemi, Obayelu and Opaluwa (2011) put healthcare utilization as the use of healthcare services by people. This level of utilization have been said to be influenced by the following factors some of which include; availability, quality and cost of services, as well as social-economic structure, and personal characteristics of the users (Chakraborty et al, 2003; Onah et al. 2009). Moreover, Leive and Xu (2008) asserted that a number of factors have been showed to be potential barriers in assessing healthcare services and these include distance and cost of travel to the health facility, socio-cultural factors and cost of service especially in developing countries of the world. Among all these factors distance and cost of travel to the healthcare facilities have been considered to be the most important factor affecting the rate at which healthcare facilities are been utilized (Awoyemi et al, 2011), this was manifested in the work of Olugbamila (2016) that accessibility to healthcare facilities is the ability of individual or community to obtain healthcare services which have been said to depend on the cost of travel and distance of the healthcare facility to place of resident (Buor, 2003).

Studies have shown that there is a correlation between residents social and economic characteristics and their level of patronage of infrastructural facilities such as healthcare facilities (Olawuni, 2008; Riman 
and Akpan 2012, Owoseni et al, 2014, Olugbamila, 2016). Owoseni et al, (2014) affirmed that the socio-economic status of a country will most likely affect the health situation, generally, the better the economy indicators, the better the health condition of the residents. Furthermore the influence of socio-economic characteristic cannot be overlook because various studies in the literature indicate an association between factors such as income, education, ethnicity, religion, culture, age, parity and decision-making power to utilization of healthcare facilities around the world (Babalola and Fatusi, 2009; Owoseni et al, 2014, Adeyinka and Olugbamila, 2016). The following socio-economic variables among others have been established to play significant role in how people put the available healthcare facilities into use.

\section{Education}

Education according to Caldwell (1979 cited in Owoseni et al, 2014) enhances peoples knowledge of modern healthcare services, improves their ability to communicate with modern healthcare providers, increases the value they place on good health and also results in heightened demand for modern healthcare services. Various studies in developing countries has consistently showed that acquired western education tend to be strongly and positively associated with utilization of healthcare facilities and services (Chakraborty et al, 2003; Kamal, 2009). It has been established that the higher a woman's level of education the more likely she is to utilize maternal healthcare services (MCHS). Studies have also revealed that the more educated women are, the more they will be able to know the importance attached to receiving prenatal care and are also more likely to know where to get it (Raghupathy, 1996). It has been argued that better educated women are more aware of health problems, know more about the availability of health care services, and use this information more effectively to maintain or achieve good health status

\section{Employment}

The working environments within which people are employed play a significant role in their access to healthcare facilities. In the work of Adamu (2011) on utilization of MHCS in Nigeria, asserted that it is widely expected that women who are working and earning money will have greater financial independence and ability to pay for healthcare services. However, MilesDoan \& Brewster (1998) argue that the aforementioned financial independence and ability to pay for healthcare services will also depend on the nature of the job, and not simply on its income generating power. Because some studies have indicated that women who engaged in less attractive job e.g. farming are less likely to utilize MHCS (Nwakoby, 1994; Addai, 2000). 


\section{Income}

Income of residents is another important variable in explaining patronage of any social services in any given area. The income is a measure of wealth and will reflect the ability of a household/resident to make decision on the type of healthcare facility to patronize. The type of facility visited, duration of visit and action taken after sickness is a function of their income. It has been established that an increase income play a substantial role in determining the rate at which people patronize the healthcare facilities (Elo, 1992 cited in Chakraborty et al, 2003). This is because the cost of seeking healthcare may include costs for transportation, user fees, medications and other supplies which people who are not earning enough or from poor background, may not have the ability to afford such, this is likely to discourage them from patronizing the available healthcare facilities because of the inability to pay for it (Adamu, 2011). Studies have established that income level of household dictate their ability to patronize and pay for available healthcare services (Olawuni, 2008; Adeyinka, 2013; Owoseni et al, 2014)

\section{The Study Area}

The study area is Owo Local Government Area (LGA) of Ondo State, Nigeria. Owo LGA is one of the eighteen (18) LGAs in Ondo State. It lies between latitude $7^{0} 11^{\prime}$ North and $5^{0} 35^{\prime}$ East of the Greenwich Meridian. It covers a total land area of $636 \mathrm{sq} \mathrm{km}$ and has an estimated population of 218,886 people (NPC, 2006). The projected population (based on the 2006 population census) was 285,597 in the year 2015. The LGA is bounded by Emure-Ise- Orun Local Government Area of Ekiti State to the North, Akure and Idanre to the East and South respectively, while Ose Local Government forms the border to the West and part of the South. River Ogbese and Ose form the natural boundaries between Owo and a few of these neighbouring Local Government Areas. 


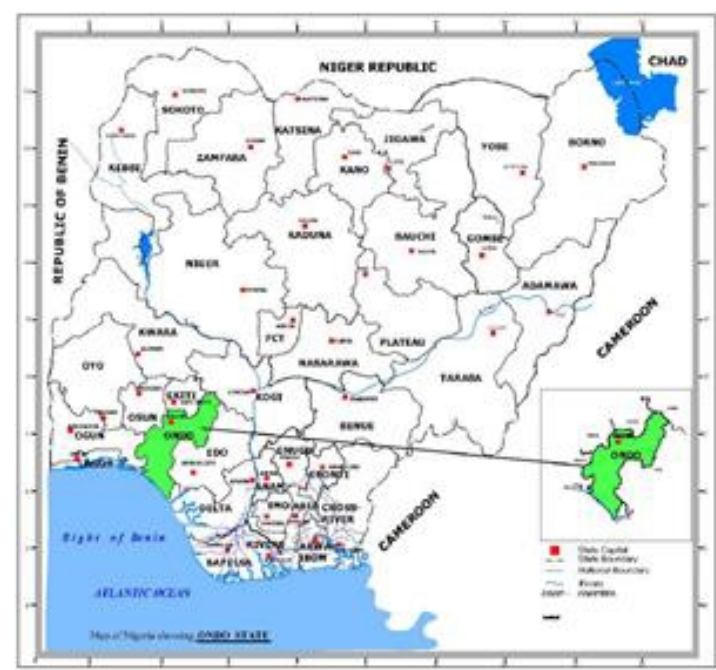

Figure 1a: Map of Nigeria Showing Ondo State

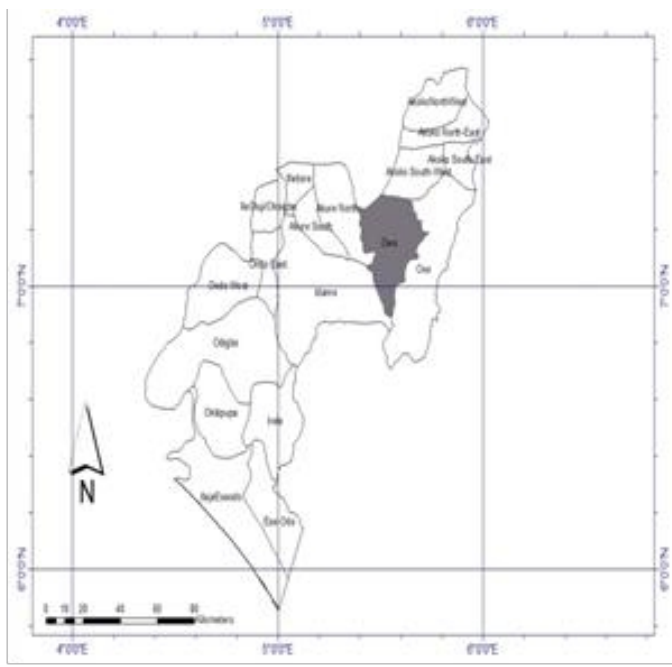

Figure 1b: Administrative Map of Ondo State Showing Owo LGA

\section{Methodology}

The data set utilized for the study were collected using a structured questionnaire administered on selected residents (health consumers) living in different settlements of Owo LGA. The study area comprised of a total of one hundred and twenty eight (128) settlements. Stratified random sampling technique was employed in selecting $10 \%$ from the identified settlements, this translate to 13 settlements. The buildings in each settlement were first listed from which $1.5 \%$ of them were surveyed. In the selected settlements, the respondents were the household heads but where the household head was not available, an adult was sampled. In all a total of 368 questionnaire were administered.

The variables that were employed in the analysis are gender, marital status, age, occupation, educational level, average monthly income and length of stay of residents. To further achieve the objective of this paper, an hypothesis was formulated thus

Ho: There is no significant relationship between the socio-economic characteristics of residents and utilization of healthcare facilities in Owo local government area of Ondo State.

H1: There is a significant relationship between the socio-economic characteristics of residents and utilization of healthcare facilities in Owo local government area of Ondo State.

The hypothesis was tested with the aid of the Chi-square $\left(\chi^{2}\right)$ test of independence in order to determine whether there is a significant relationship between socio-economic characteristics of residents and their utilization of healthcare facilities in the study area. In testing the hypothesis, the P-value 
was considered. When the P-value is less than 0.05 the null hypothesis (Ho) is rejected while the alternative hypothesis $(\mathrm{H} 1)$ is accepted. On the other hand, when the P-value is higher than 0.05 , the hypothesis is rejected.

\section{Result and Discussion}

\section{Gender of Residents and Frequency of Visits to Healthcare Facilities}

Table 1 revealed that the male patrons that visited the healthcare facilities in less than 5 times accounted for $55.4 \%$ and between 5 - 10 times $(25.9 \%) ; 11$ - 15 times $(11.4 \%) ; 16$ - 20 times $(5.7 \%)$ and visits of over 20 times accounted for $1.6 \%$. For the females, visits of less than 5 times accounted for $49.1 \%$; 5 - 10 times (32.0\%); 11 - 15 times (8.0\%); 16 - 20 times $(6.3 \%)$ and visits of above 20 times $(4.6 \%)$. The information presented on the gender frequency of visits revealed a decline in the number of people visiting the healthcare facilities as the number of visits increased.

Table 1: Gender and Frequency of Visit to Healthcare Facilities

\begin{tabular}{|l|r|l|l|l|l|l|}
\hline \multirow{2}{*}{ Gender } & \multicolumn{4}{|l|}{ Frequency of Visit } & \multicolumn{1}{|l|}{ Total } \\
\cline { 2 - 6 } & Less than 5 tim & $\begin{array}{l}5-10 \\
\text { times }\end{array}$ & $\begin{array}{l}11-15 \\
\text { Times }\end{array}$ & $\begin{array}{l}16-20 \\
\text { Times }\end{array}$ & $\begin{array}{l}\text { Above 20 } \\
\text { times }\end{array}$ & \\
\hline Males & $107(55.4 \%)$ & $50(25.9 \%)$ & $22(11.4 \%)$ & $11(5.7 \%)$ & $3(1.6 \%)$ & $103(100.0 \%)$ \\
\hline Females & $86(49.1 \%)$ & $56(32.0 \%)$ & $14(8.0 \%)$ & $11(6.3 \%)$ & $8(4.6 \%)$ & $175(100.0 \%)$ \\
\hline Total & $193(52.4 \%)$ & $106(28.8 \%)$ & $36(9.8 \%)$ & $22(6.0 \%)$ & $11(3.0 \%)$ & $368(100.0 \%)$ \\
\hline
\end{tabular}

Source: Authors' fieldwork, 2015

\section{Marital Status and Frequency of Visit to Healthcare Facilities}

The marital distribution of the respondents shows that married people were more likely to utilize healthcare facilities than other category of respondents. Findings presented in Table 2 showed that majority of the different categories of marital status (52.4\%) patronized less than 5 times; $28.8 \%$ in 5 - 10 times; $9.8 \%$ in 11 - 15 times; and the remaining $6.0 \%$ and $3.0 \%$ in $16-20$ times and above 20 times respectively. The findings further revealed that married people with the support of their spouse are more likely to utilize healthcare facilities as compared to the singles, divorced and the widowed.

Table 2: Marital Status and Frequency of Visit to Healthcare Facilities

\begin{tabular}{|r|r|r|r|r|r|r|}
\hline \multirow{2}{*}{$\begin{array}{r}\text { Marital } \\
\text { Status }\end{array}$} & \multicolumn{5}{|c|}{ Frequency of Visit } & \multirow{2}{*}{ Total } \\
\cline { 2 - 6 } & $\begin{array}{r}\text { Less than } \\
\text { Times }\end{array}$ & $\begin{array}{r}5-10 \\
\text { times }\end{array}$ & $\begin{array}{r}11-15 \\
\text { times }\end{array}$ & $\begin{array}{r}16-20 \\
\text { Times }\end{array}$ & $\begin{array}{r}\text { Above } 2 \\
\text { times }\end{array}$ & \\
\hline Single & $79(67.5 \%$ & $16(13.7 \%)$ & $13(11.1 \%$ & $6(5.1$ & $3(2.6$ & $117(100.0 \%$ \\
\hline Married & $102(46.2 \%$ & $80(36.2 \%$ & $18(8.1 \%$ & $14(6.3 \%$ & $7(3.2$ & $221(100.0 \%$ \\
\hline $\begin{array}{r}\text { Separate } \\
\text { Divorce }\end{array}$ & $6(66.7 \%$ & $1(11.1 \%$ & $1(11.1 \%$ & $1(11.1 \%$ & $0(0.0$ & $9(100.0 \%$ \\
\hline Widowe & $6(28.6 \%$ & $9(42.9 \%)$ & $4(19.0$ & $1(4.8 \%$ & $1(4.8$ & $21(100.0 \%$ \\
\hline Total & $193(52.4 \%$ & $106(28.8 \%$ & $36(9.8 \%$ & $22(6.0 \%$ & $11(3.0 \%$ & $368(100.0 \%$ \\
\hline
\end{tabular}

Source: Authors' fieldwork, 2015 


\section{Age Distribution of Residents and Frequency of Visits to Healthcare Facilities}

The age of the household head in the study area were grouped into three. These were: 19-30 years (the youths), 31-55 years (the young adults) and 55 years and above (the adults) (Olugbamila, 2016). The relationship between age distribution and frequency of visits to healthcare facilities presented in Table 3 showed that the young adult utilized the healthcare facilities more than the other categories and this represent $46.2 \%$ of the population. It was evident that majority of the youth $(59.4 \%)$ visited the healthcare facilities less than 5 times, $45.6 \%$ of the young adult which constitute the majority also visited the facilities less than 5 times, also majority of the adults $(54.8 \%)$ visited the healthcare facilities between less than 5 times. This shows that the area has a more active population which requires health services for better productivity. The above finding is in agreement with previous studies that age is a determinant factor in knowledge of availability and utilization of healthcare facility (Adamu, 2011).

Table 3: Age Distribution of Residents and Frequency of Visits to Healthcare Facilities

\begin{tabular}{|c|r|r|r|r|r|r|}
\hline \multirow{2}{*}{ Age } & \multicolumn{5}{|c|}{ Frequency of Visit } & \multirow{2}{*}{ Total } \\
\cline { 2 - 6 } & $\begin{array}{r}\text { Less than } \\
\text { Times }\end{array}$ & $\begin{array}{r}5-10 \\
\text { Times }\end{array}$ & $\begin{array}{c}11-15 \\
\text { Times }\end{array}$ & $\begin{array}{r}16-20 \\
\text { Times }\end{array}$ & $\begin{array}{r}\text { Above 2 } \\
\text { times }\end{array}$ & \\
\hline $\begin{array}{c}18-30 \text { years } \\
\text { (Youth) }\end{array}$ & $92(59.4 \%$ & $38(24.5 \%)$ & $16(10.3 \%$ & $8(5.2 \%$ & $1(1.6 \%$ & $155(100.0 \%$ \\
\hline $\begin{array}{c}31-55 \text { years } \\
\text { (Young Adult }\end{array}$ & $77(45.6 \%$ & $55(32.5 \%)$ & $16(9.5 \%$ & $14(8.3 \%$ & $7(4.1 \%$ & $169(100.0 \%$ \\
\hline $\begin{array}{c}35-44 \text { years } \\
\text { (Adult) }\end{array}$ & $23(54.8 \%$ & $12(28.6 \%)$ & $4(9.5 \%)$ & $0(0.0 \%$ & $3(7.1 \%$ & $42(100.0 \%$ \\
\hline Total & $192(52.5 \%$ & $105(28.7 \%$ & $36(9.8 \%)$ & $22(6.0 \%$ & $11(3.0 \%$ & $366(100.0 \%$ \\
\hline
\end{tabular}

Source: Authors' fieldwork, 2015

\section{Residents Occupation and Frequency of Visits to Healthcare Facilities}

Occupation of residents or the profession an individual engages in is a determinant of their level of income (Jayamala, 2008; Sanni et al, 2010). Okafor (1983) observed that civil servant utilize healthcare facilities more than farmers, traders and craftsmen, and suggests that such differential utilization can be accounted for by time factor. From the summary presented in Table 4, it was evident that traders utilized the healthcare facilities more than the other categories and this accounted for $28.8 \%$ of the population. The Table further revealed that majority of the different categories of occupation $(52.1 \%)$ utilized the healthcare facilities less than 5 times, $20.0 \%$ in $5-10$ times, $9.9 \%$ in $10-15$ times, $6.0 \%$ in $16-20$ times and $3.0 \%$ more than 20 times respectively. 
Table 4: Residents Occupation and Frequency of Visits to Healthcare Facilities

\begin{tabular}{|l|c|c|c|c|c|c|}
\hline \multirow{2}{*}{ Occupation } & \multicolumn{2}{|l|}{ Frequency of Visit } & \multicolumn{1}{|c|}{ Total } \\
\cline { 2 - 6 } & $\begin{array}{l}\text { Less than 5 } \\
\text { Times }\end{array}$ & $\begin{array}{l}5-10 \\
\text { Times }\end{array}$ & $\begin{array}{l}11-15 \\
\text { Times }\end{array}$ & $\begin{array}{l}16-20 \\
\text { Times }\end{array}$ & $\begin{array}{l}\text { Above 20 } \\
\text { times }\end{array}$ & \\
\hline Schooling & $37(57.6 \%)$ & $14(21.9 \%)$ & $7(10.9 \%)$ & $4(6.2 \%)$ & $2(3.1 \%)$ & $64(100.0 \%)$ \\
\hline Farming & $24(48.0 \%)$ & $14(28.0 \%)$ & $7(14.0 \%)$ & $4(8.0 \%)$ & $1(2.0 \%)$ & $50(100.0 \%)$ \\
\hline Trading & $54(50.9 \%)$ & $37(34.9 \%)$ & $8(7.5 \%)$ & $7(6.6 \%)$ & $0(0.0 \%)$ & $106(100.0 \%)$ \\
\hline Civil Servant & $27(51.9 \%)$ & $14(26.9 \%)$ & $5(9.6 \%)$ & $1(1.9 \%)$ & $5(9.6 \%)$ & $52(100.0 \%)$ \\
\hline Artisan & $39(55.7 \%)$ & $21(30.0 \%)$ & $7(10.0 \%)$ & $2(2.9 \%)$ & $1(1.4 \%)$ & $70(100.0 \%)$ \\
\hline Others & $9(39.1 \%)$ & $6(26.1 \%)$ & $2(8.7 \%)$ & $4(17.4 \%$ & $2(8.7 \%)$ & $23(100.0 \%)$ \\
\hline Total & $190(52.1 \%)$ & $106(29.0 \%)$ & $36(9.9 \%)$ & $22(6.0 \%)$ & $11(3.0 \%)$ & $368(100.0 \%$ \\
\hline
\end{tabular}

Source: Authors' fieldwork, 2015

\section{Educational Level and Frequency of Visits to Healthcare Facilities}

The educational level of household members is among the most important characteristics of a household because it is associated with many factors that have a significant impact on health-seeking behaviours, reproductive behaviours, use of contraception, and children's health status. The work of Riman and Akpan (2012) posited that an improvement in educational status of the population is more likely to improve the health status of the people. Table 5 therefore presents information on the educational level and frequency of visits to healthcare facilities in the study area. The Table revealed that respondents that had at least secondary/technical education utilized the healthcare facilities more than the other levels of education and this accounted for $49.7 \%$ of the total sampled. Further analysis in the Table revealed that majority of the residents (51.7\%) across the different levels of education visited the healthcare facilities less than 5 times.

Table 5: Educational Level and Frequency of Visits to Healthcare Facilities

\begin{tabular}{|c|c|c|c|c|c|c|}
\hline \multirow{2}{*}{$\begin{array}{l}\text { Level of } \\
\text { Education }\end{array}$} & \multicolumn{5}{|c|}{ Frequency of Visit } & \multirow[t]{2}{*}{ Total } \\
\hline & $\begin{array}{c}\text { Less than } \\
\text { Times }\end{array}$ & $\begin{array}{l}5-10 \\
\text { Times }\end{array}$ & $\begin{array}{c}11-15 \\
\text { Times }\end{array}$ & $\begin{array}{r}16-20 \\
\text { Times } \\
\end{array}$ & $\begin{array}{c}\text { Above } 2 \\
\text { times } \\
\end{array}$ & \\
\hline No Formal Education & $20(57.1 \%$ & $9(25.7 \%$ & $4(11.4 \%$ & $0(0.0 \%)$ & $2(5.7 \%$ & $35(100.0 \%$ \\
\hline Primary & $25(53.2 \%$ & $16(34.0 \%$ & $4(8.5 \%$ & $2(4.3 \%)$ & $0(0.0 \%$ & $47(100.0 \%$ \\
\hline Secondary/Technica & $85(46.7 \%$ & $57(31.3 \%$ & $21(11.5 \%$ & $16(8.8 \%$ & $3(1.6 \%$ & $182(100.0 \%$ \\
\hline Tertiary & $51(58.0 \%)$ & $22(25.0 \%)$ & $7(8.0 \%$ & $2(2.3 \%)$ & $6(6.8 \%$ & $88(100.0 \%$ \\
\hline Others & $5(62.5 \%$ & $1(12.5 \%$ & $0(0.0 \%$ & $2(25.0 \%$ & $0(0.0 \%$ & $8(100.0 \%$ \\
\hline Total & $186(51.7 \%$ & $105(29.2 \%$ & $36(10.0 \%$ & $22(6.1 \%$ & $11(3.1 \%$ & $368(100.0 \%$ \\
\hline
\end{tabular}

Source: Authors' fieldwork, 2015

\section{Average Monthly Income and Frequency of Visits to Healthcare Facilities}

Income of residents is another important variable in explaining patronage of any social services in any given area. The income is a measure of wealth and will reflect the ability of a household/resident to make decision on the type of healthcare facility to patronize. The type of facility visited, 
duration of visit and action taken after sickness is a function of their income. Where the household income is not sufficient, it will leave the household less with no option than to resolve to self medication.

The income of the household heads in the study area were grouped into three, those who earn below $\$ 20,000.00$ per month were regarded as low income earners (LI), $\$ 20,000.00$ - $\$ 60,000.00$ per month were referred to as middle income earners (MI), while the high income earners (HI) earn above $\$ 60,000.00$ per month. From the classification and as presented in Table 6, it was revealed that larger percentage of respondents were low income earners. This accounted for $60.3 \%$ of the total respondents while $32.8 \%$ were middle income earners and only $6.9 \%$ residents were categorized as high income earners in the study area. The Table further revealed that majority of the residents across the different income group visited the healthcare facilities in less than 5 times, and this accounted for $59.5 \%$ of the LI, $40.7 \%$ of the MI and $55.6 \%$ of the HI.

Table 6: Average Monthly Income and Frequency of Visits to Healthcare Facilities

\begin{tabular}{|c|c|c|c|c|c|c|}
\hline \multirow[t]{2}{*}{ Income } & \multicolumn{5}{|c|}{ Frequency of Visit } & \multirow[t]{2}{*}{ Total } \\
\hline & $\begin{array}{l}\text { Less that } \\
5 \text { Times }\end{array}$ & \begin{tabular}{l|}
$5-10$ \\
Times
\end{tabular} & $\begin{array}{c}11-15 \\
\text { Times }\end{array}$ & $\begin{array}{r}16-2 \\
\text { Times }\end{array}$ & $\begin{array}{c}\text { Above } 2 \\
\text { times }\end{array}$ & \\
\hline Below $\$ 20,000$ (LI & $94(59.5 \%$ & $40(25.3 \%$ & $14(8.9 \%$ & $9(5.7 \% \mathrm{~d}$ & $1(0.6 \%$ & $158(100.0 \%$ \\
\hline $\begin{array}{c}\$ 20,000-\$ 60,000 \\
(\mathrm{MI})\end{array}$ & $35(40.7 \%$ & $29(33.7 \%$ & $6(7.0 \%$ & $8(9.3 \%$ & $8(9.3 \%$ & $86(100.0 \%$ \\
\hline Above $\$ 60,000(\mathrm{HI}$ & $10(55.6 \%$ & $7(38.9 \%$ & $0(0.0 \%$ & $0(0.0 \%$ & $1(5.6 \%$ & $18(100.0 \%$ \\
\hline Total & $139(53.1 \%$ & $76(29.0 \%$ & $20(7.6 \%$ & $17(6.5 \%$ & $10(3.8 \%$ & $262(100.0 \%$ \\
\hline
\end{tabular}

Source: Authors' fieldwork, 2015

\section{Residents Length of Stay and Frequency of Visits to Healthcare Facilities}

The longer the years of stay in any particular locality, the better the opportunity to have the knowledge about the competence, the cost of treatment and hospitality of workers in health facilities within and outside their place of residence (Olujimi, 2006). The length of stay in a particular area provides very good background knowledge in the successful treatment history on available healthcare facilities in and around the community. Table 7 revealed the proportion of residents who had resided in the study area between 1-10 years accounting for $58.3 \%$ while residents that had resided in the study area between 11-25 years, 26-40 years and above 40 years accounted for $25.8 \%, 3.8 \%$ and $12.1 \%$ respectively. The Table further revealed that $53.6 \%$ of the total respondents had visited healthcare facilities in less than 5 times, $29.9 \%$ visited between 5-10 times, while the remaining $8.4 \%, 4.9 \%$ and $3.2 \%$ had visited the facilities between 11-15 times, 16-20 times and above 20 times respectively 
Table 7: Residents Length of Stay and Frequency of Visits to Healthcare Facilities

\begin{tabular}{|l|l|l|l|l|l|l|}
\hline \multirow{2}{*}{ Length of Stay } & \multicolumn{2}{|l|}{ Frequency of Visit } & \multirow{2}{*}{ Total } \\
\cline { 2 - 6 } & $\begin{array}{l}\text { Less than 5 } \\
\text { Times }\end{array}$ & $\begin{array}{l}5-10 \\
\text { Times }\end{array}$ & $\begin{array}{l}11-15 \\
\text { Times }\end{array}$ & $\begin{array}{l}16-20 \\
\text { Times }\end{array}$ & $\begin{array}{l}\text { Above 20 } \\
\text { Times }\end{array}$ & \\
\hline < than 10 years & $120(59.7 \%)$ & $54(26.9 \%)$ & $16(8.0 \%)$ & $6(3.0 \%)$ & $5(2.5 \%)$ & $201(100.0 \%)$ \\
\hline $11-25$ years & $39(43.8 \%)$ & $33(37.1 \%)$ & $10(11.2 \%)$ & $6(6.7 \%)$ & $1(1.1 \%)$ & $89(100.0 \%)$ \\
\hline $26-40$ years & $5(38.5 \%)$ & $4(30.8 \%)$ & $2(15.4 \%)$ & $1(7.7 \%)$ & $1(7.7 \%)$ & $13(100.0 \%)$ \\
\hline$>40$ years & $21(50.0 \%)$ & $12(28.6 \%)$ & $1(2.4 \%)$ & $4(9.5 \%)$ & $4(9.5 \%)$ & $42(100.0 \%)$ \\
\hline Total & $185(53.6 \%)$ & $103(29.9 \%)$ & $29(8.4 \%)$ & $17(4.9 \%)$ & $11(3.2 \%)$ & $345(100.0 \%)$ \\
\hline
\end{tabular}

Source: Authors' fieldwork, 2015

\section{Test of Hypothesis}

Ho: There is no significant relationship between the socio-economic characteristics of residents and utilization of healthcare facilities in Owo local government area of Ondo State.

H1: There is a significant relationship between the socio-economic characteristics of residents and utilization of healthcare facilities in Owo local government area of Ondo State.

This hypothesis was tested with the aid of the Chi-square $\left(\chi^{2}\right)$ test of independence in order to determine whether there is a significant relationship between socio-economic characteristics of residents and their utilization of healthcare facilities. The result is presented in Table 8 .

Seven (7) variables were cross-tabulated against the frequency of visit to healthcare facilities. These variables are gender, marital status, age, educational level, occupation, average monthly income and length of stay of residents. The result presented in Table 8 revealed that there is a significant relationship between the frequency of visit to healthcare facilities and income of residents $\left(\chi^{2}=20.961\right.$ at the degree of freedom of 8 and significant at $\mathrm{p}=0.007$ ). This explains that monthly income is a great determinant of utilization of healthcare facilities and this is a confirmation of earlier studies that increased income has a positive effect on the utilization of modern healthcare facility (Elo, 1992) and also family income is an important determinant of the pattern of use of healthcare facilities (Owoseni et al, 2014).

Similarly, frequency of visits to healthcare facilities and level of education of residents also showed a significant relationship $\left(\chi^{2}=20.409, \mathrm{p}\right.$ $=0.012$ ). This shows that the higher the level of respondents education, the higher the utilization of healthcare facilities and vice versa. The above confirms the findings that the educated are more cautious of their health and tend to use healthcare facilities more (Caldwell, 1979 cited in Owoseni et al, 2014). Moreover there is a significant relationship between frequency of visits to healthcare facilities and marital status of residents $\left(\chi^{2}=29.175\right.$ at the degree of freedom of 12 and significant at $p=0.004$ level). Also a 
significant relationship exist between frequency of visits and residents length of stay in the study area $\left(\chi^{2}=21.036, \mathrm{p}=0.050\right)$.

However, there is no significant relationship between the frequency of visits to healthcare facilities and gender of residents $\left(\chi^{2}=5.809\right.$ at df of 4 and $p=0.214$ level), also frequency of visit to healthcare facilities and age of respondents showed no significant relationship $\left(\chi^{2}=15.016\right.$ at df of 8 and at $\mathrm{p}=0.059$ level). In addition, occupation have no significant relationship with the frequency of visits to healthcare facilities in the study area $\left(\chi^{2}=27.511\right.$, $\mathrm{p}=0.121$ ). We therefore reject the null hypothesis (Ho) thus there is a significant relationship between the residents socio-economic characteristics and utilization (frequency of visits) of healthcare facilities in the study area.

This is in line with the study of Owoseni et al, (2014) in the study of the Socio-economic status and utilization of healthcare facilities in rural Ekiti, Nigeria where the hypothesis tested confirmed that there is a significant relationship between people's educational attainment and their utilization of healthcare facilities in the study area.

Table 8: Chi-square Test for Socio-Economic Characteristics of Respondents and Frequency of Visits to Healthcare Facilities

\begin{tabular}{|l|l|r|l|l|}
\hline Pearson Chi-Square & Value & Df & Asymp. Sig. (2-sided) & Comments \\
\hline Gender & 5.809 & 4 & 0.214 & Not Significant \\
\hline Marital Status & 29.175 & 12 & 0.004 & Significant \\
\hline Age & 15.016 & 8 & 0.059 & Not Significant \\
\hline Occupation & 27.511 & 20 & 0.121 & Not Significant \\
\hline Level of Education & 20.409 & 8 & 0.012 & Significant \\
\hline Income & 20.961 & 8 & 0.007 & Significant \\
\hline Length of Stay & 21.036 & 12 & 0.050 & Significant \\
\hline
\end{tabular}

Source: Authors' fieldwork, 2015

\section{Conclusion}

Good healthcare system is vital in any country, not only for the purpose of maintaining a healthy populace, but also as a matter of national security. A healthy country is a wealthy country, with a thriving human resource the country can invest in to move the nation to greater heights. In this regard, this research work has examined the relationship between socioeconomic status and utilization of healthcare facilities among the people of Owo LGA of Ondo State.

The socio-economic factors considered were gender, age, marital status, educational level, income, occupation and residents' length of stay. The study revealed that the number of people visiting the health facilities diminishes as the number of visits increases, this is true of all the socioeconomic attributes considered, it is evident from the study that majority of the residents visited the healthcare facilities in less than 5 times. The study therefore confirmed the fact that socio-economic characteristics of residents 
play a significant role in determining their utilization of healthcare facilities and also the extent of the utilization of healthcare facilities is a function of the socio-economic factors. This paper therefore concludes by advocating for the following

$>$ There should be adequate public enlightenment with the involvement of traditional institutions on the use of healthcare facilities. It is believe that this awareness will have long lasting effects on the perception and attitude of people towards utilization of health facility which invariably will reduce both health morbidity and mortality.

$>$ Modern healthcare facilities should be made available and accessible to the people at minimal cost as well as locate the facilities close to the populace, this is believed will reduce the time spent and the cost of travelling to healthcare facilities which will invariably increase the utilization of the available healthcare facilities.

$>$ Efforts should be put in place to improve the socio-economic status of individuals through multi-sectoral development activities such as micro-credit facilities, empowerment/training and provision of employment opportunities which is believed will invariably improve their access and utilization of healthcare facilities.

\section{References:}

1. Addai, I. (2000). Determinants of Use of Maternal-Child Health Services in Rural Ghana. Journal of Biosocial Science. 32(1): 1-11.

2. Adamu, H.S (2011). Utilization of Maternal Health Care Services in Nigeria: An Analysis of Regional Differences in the Patterns and Determinants of Maternal Health Care. An M.Sc. thesis submitted to the Department of Public Health, The University of Liverpool.

3. Adesanya, A., Adeniji, K and Daramola A.Y. (2002). Transport Perspective of Poverty in Nigeria in Ajakaiye, D.O. and. Olomola, A.S (Eds.) Poverty in Nigeria: A Multi-dimensional Perspective: 235-283.

4. Adetunji, M.A. (2010). Spatial Analysis of Urban Mobility Pattern in Ilesa, Osun State. A Ph.D Thesis submitted to the Department of Geography, Obafemi Awolowo University, Ile-Ife, Nigeria.

5. Adeyinka, M.A. (2013). Spatial Distribution, Pattern and Accessibility of Urban Population to Health Facilities in Southwestern Nigeria: The Case Study of Ilesa. Mediterranean Journal of Social Science. 4(2): 425-436.

6. Adeyinka, S.A (2006). Locational Analysis of Health Care Facilities in Ife Region. A Ph.D Thesis submitted to the Department of Urban and Regional Planning, Obafemi Awolowo University, Ile-Ife, Nigeria. 
7. Adeyinka, S.A. and Olugbamila, O.B. (2016). Correlates of Residents Socio-Economic Characteristics and Frequency of Visits to Healthcare Facilities in Ondo State, Nigeria. Journal of Research on Humanities and Social Science. 6(18): 7-16.

8. Awoyemi, T.T, Obayelu, O.A. and Opaluwa, H.I. (2011). Effect of Distance on Utilization of Healthcare Services in Rural Kogi State, Nigeria. Journal of Human Ecology. 35(1): 1-9.

9. Babalola, S. and Fatusi, A. (2009). Determinants of use of maternal health services in Nigeria - looking beyond individual and household factors. BMC Pregnancy and Childbirth; 9: 43, doi: 10.1186/14712393-9-43.

10. Balogun, T.F. and Alaegor, A.G (2006). An Evaluation of the Spatial Distribution of Healthcare Facilities in Edo State. Knowledge Review. 12(1): 71-78.

11. Buor, D. (2003). Analysis of the Primacy of Distance in the Utilization of Health Services in Ahafo-Ano South District, Ghana. International Journal of Health Planning and Management.18(4): 293-311.

12. Chakraborty, N, Islam M.A, Chowdhury R.I, Bari W.W. and Akhter H.H. (2003). Determinants of the use of maternal health services in rural Bangladesh. Health Promotion International, 18(4): 327-337.

13. Elo, T.I. (1992). Utilization of maternal health-care services in Peru: the role of women's education. Health Transition Review. 2: 49-69.

14. Federal Ministry of Health (FMOH) (2004). Health Care in Nigeria. Annual Bulletin of the Federal Ministry of Health, Abuja, Nigeria.

15. Ibor, U.W. and Atomode, T.I. (2014). Health Service Characteristics and Utilization in Calabar Metropolis, Cross River State, Nigeria. Academic Journal of Interdisciplinary Studies. 3(1): 265-270.

16. Jayamala, M (2008). Trends and Spatial Patterns of Crime in India: A Case Study of a District in India. A Doctoral Dissertation in Sociology, Annamalai University, India.

17. Kamal, S.M.M. (2009). Factors Affecting Utilization of Skilled Maternity Care Services among Married Adolescents in Bangladesh. Asian Population Studies, 5(2): 153-170.

18. Kwaku, K.K. (2008). Spatial Accessibility to Health Care Facilities in Ajumako-Enyan-Essiam and Upper Denkyira Districts in the Central Region of Ghana. Norwegian Journal of Geography. 62(3): 203-209.

19. Leive, A, and Xu, K. (2008). Coping with out-of-pocket health payments: empirical evidence from 15 African countries. Bulletin of the World Health Organization. 86: 849-856. 
20. Miles-Doan, R. and Brewster, K. L. (1998). The Impact of Type of Employment on Women's Use of Prenatal-care Services and Family Planning in Urban Cebu, the Philippines. Studies in Family Planning, 29(1): 69-78.

21. Nwakoby, B.N. (1994). Use of Obstetric Services in Rural Nigeria. Journal of social Health 114(3): 132-136.

22. Okafor, S.I. (1983). Factors Affecting the Frequency of Hospital Trips among a Predominantly Rural Population. Social Science and Medicine. 16: 19-21.

23. Olawuni, P.O. (2008). Socio-Economic Factors and Residents Health in Nigerian Urban Centres. African Research Review. 2(3): 236-248.

24. Olugbamila, O.B. (2016). The Study of the Distribution and Patronage Patterns of Healthcare Facilities in Ondo State, Nigeria. A Ph.D Thesis submitted to the Department of Urban and Regional Planning, Obafemi Awolowo University, Ile-Ife, Nigeria.

25. Olujimi, J.A.B. (2006). Significant Factors Affecting Patronage of Health Facilities by Rural Dwellers in Owo Region, Nigeria. The Social Sciences. 1(3):206-215.

26. Onah, H, Ikeako L, Iloabachie, G. (2009). Factors associated with the use of maternity services in Enugu, south-eastern Nigeria. Journal Social Science and Medicine, 63(7): 1870-1878.

27. Owoseni, J. S, Oluwadare, C.T., Jegede, L. I. and Ibikunle, A. M. (2014). Socio-economic status and utilization of healthcare facilities in rural Ekiti, Nigeria. Standard Research Journal of Medicine and Medical Sciences. $\quad 2(1): \quad 001-043$. http://www.standresjournals.org/journals/SRJMMS.

28. Raghupathy, S. (1996). Education and the use of maternal healthcare in Thailand. Journal of Social Science \& Medicine. 43(4): 459-471.

29. Riman, H.B. and Akpan E.S (2012). Healthcare Financing and Health Outcome in Nigeria: A State Level Study Using Multiviarate Analysis. International Journal of Humanities and Social Science. 2(15): 296-309.

30. Sanni, L. (2010). Distribution Pattern of Healthcare Facilities in Osun State, Nigeria. Ethiopian Journal of Environmental Study and Management. 3(2): 65-76.

31. UN. (2000). The Right to the Highest Attainable Standard of Health: 11/08/2000. E/C.12/2000/4. (General Comments). Office of the United Nations High Commissioner for Human Rights. http://www.unhchr.ch/tbs/doc.nsf/(symbol)/E.C.12.2000.4.En.

Accessed on $\quad 9^{\text {th }} \quad$ May, 2016

Yang, D., George, R., \& Mullner, R. (2006). Comparing GIS-Based 
Methods of Measuring Spatial Accessibility to Health Services. Journal of Medical Systems, 30(1): 23-32. 